$\underline{\text { Review Article }}$

\title{
CONTRIBUTION OF PHARMACIST FOR TRANSFORMING GLOBAL HEALTH CARE SYSTEM: ROLES AND OPPURTUNITIES
}

\author{
ZULFKAR LATIEF QADRIE ${ }^{1}$, SHAHID UD DIN WANI ${ }^{*}$, SURYA PRAKASH GAUTAM²
}

\author{
${ }^{1}$ Department of Pharmacology, CT Institute of Pharmaceutical Sciences, CT Group of Institutions, Jalandhar, India-144020, ${ }^{2}$ Department \\ of Pharmaceutics, CT Institute of Pharmaceutical Sciences, CT Group of Institutions, Jalandhar, India-144020 \\ Email: shahidpharma2013@gmail.com
}

Received: 25 Mar 2020, Revised and Accepted: 28 May 2020

\begin{abstract}
Fifty years ago, the essential job of drug specialists has only been to apportion solutions. Giving clinical drug store administrations at the medical clinics' wards spoke to the development of the calling. Be that as it may, the social insurance framework, around the world, is persistently creating. Today, the drug specialist's unmistakable new jobs have emphatically added to human services and society around the world. Drug specialists are presently accepting more prominent accountability for patients' wellbeing status and advancing the results of medication use. They give human services counsel and oversee interminable ailments. Different orders of social insurance where particular drug specialists are utilized to incorporate oncology offices, irresistible sickness control, general wellbeing, medicate data, toxicology and toxic substance control, atomic medication, and sustenance support. In any case, a fitting determination, instruction, preparing and workforce arranging to speak to an essential for the cutting edge drug store jobs. Specific instruction programs are required. New drug specialists should be appropriately qualified. By and by, rehearsing drug specialists need to adjust the essential information and required aptitudes, therefore, they can build up their training and jobs to address evolving issues.
\end{abstract}

Keywords: Pharmacy Management, Healthcare Management, Job Opportunities, Pharmacists

(C) 2020 The Authors. Published by Innovare Academic Sciences Pvt Ltd. This is an open access article under the CC BY license (http://creativecommons.org/licenses/by/4.0/) DOI: http://dx.doi.org/10.22159/ijcpr.2020v12i4.39080. Journal homepage: https://innovareacademics.in/journals/index.php/ijcpr

\section{INTRODUCTION}

Fifty years ago, the essential job of drug specialists has only been to apportion solutions. Giving clinical drug store administrations at the medical clinics' wards spoke to the development of the calling. Be that as it may, the social insurance framework, around the world, is persistently creating. General wellbeing requests and network desires are expanding. The drug specialists' particular information, foundation in complex pharmaceutical science, medicate improvement and expert judgment makes drug specialists interestingly positioned in the social insurance group to oversee and regularly to lead in the expanding intricacy and customized nature of medication and ailments.

In this manner, the drug specialist's job moved from the medication focused assistance, as a meditation master, to a patient guardian, including adequacy, wellbeing, and patient experience. Drug store practice is a comprehensive term that consolidates not just components of the clinical drug store and the legitimate and moral parts of expert practice yet besides different points of view which help with comprehension of the more extensive social setting in which pharmaceutical administrations are conveyed [1].

Today, the drug specialist's unmistakable new jobs have emphatically added to human services and society around the world. Drug specialists are presently accepting more prominent accountability for patients' wellbeing status and advancing the results of medication use. They give human services counsel and oversee interminable ailments. Moreover, they have a prescriptive position (starting remedies) for determining conditions; minor diseases or conditions; or in crisis conditions. The various job opportunities are enlisted in (table 1) for Pharmacy Graduates. They can re-establish or adjust solutions for proceeding with care. They may make restorative replacements. Drug specialists regulate medications to patients and have an infusion authority of antibodies, including flu immunization and travel immunizations, or for all immunizations just as in certain conditions of all parenteral medication items. Besides, drug specialists utilize the counsel rooms in their drug stores to direct centers of smoking discontinuance or give diabetes training and request symptomatic research facility tests and decipher test results. They perform home medicine surveys too [2-4].

The drug store field includes numerous orders, all of which identity with information on sedate treatments [5]. Today, expert drug specialists work at the specific clinical focuses; basic consideration drug specialists assume a significant job in emergency clinic escalated care units and mental drug specialists are associated with considering mental patients [6].

Pediatric and geriatric drug specialists are specific to give pharmaceutical consideration to youngsters and older, separately. Notwithstanding, walking drug specialists and home-care drug specialists give care to outpatients and in claims to fame, for example, HIV or renal transplantation. Different orders of social insurance where particular drug specialists are utilized to incorporate oncology offices, irresistible sickness control, general wellbeing, medicate data, toxicology and toxic substance control, atomic medication, and sustenance support. Instances of drug specialists' all-inclusive jobs from nations around the world are to be introduced [7].

In any case, a fitting determination, instruction, preparing and workforce arranging to speak to an essential for the cutting edge drug store jobs. Specific instruction programs are required. New drug specialists should be appropriately qualified. Itemized clinical preparation is being directed $[8,9]$. Drug store instruction must get ready alumni to be researchers, researchers, specialists, and experts. The scholastic investigation of drug store practice incorporates points, for example, wellbeing training and advancement; social drug store, correspondence and guiding, conduct change, lawful and moral angles; proficient decisions; wellbeing, pharmaco-financial aspects, and pharmaco-the study of disease transmission [10]. 
Table 1: Job opportunities for pharmacy graduates

\begin{tabular}{|c|c|c|}
\hline S. No. & Field of pharmacy & Job opportunities \\
\hline 1 & Production & $\begin{array}{l}\text { Formulation, Bulk Drugs, Cosmetics, OTC, Excepient, Intermediates, Medical devices, Parentrals, } \\
\text { Diagnostics, Raw Materials, Galenicals, Production Control, Repacking, Packaging. }\end{array}$ \\
\hline 2 & Marketing & $\begin{array}{l}\text { Sales Management, Marketing Management, Campaign Management, Promotion Strategies, } \\
\text { Advertising, Product Management, Market research. }\end{array}$ \\
\hline 3 & Research and Development & $\begin{array}{l}\text { New Drug Discovery, NDDS, Formulation Development, Molecular Modeling, Molecular Biology, } \\
\text { Bioinformatics, Toxicology, Analytical Research, Biotechnology, Herbal research. Tissue Culture. }\end{array}$ \\
\hline 4 & Formulation and Development & Formulation Development, Galenicals Research \\
\hline 5 & Clinical Research & Pharmacovigilance, CRO, Clinical Trials, Clinical Data Management, Contract Research (Formulation) \\
\hline 6 & Operation Room Pharmacist & Operation Room Organizer, Pre-Operative Care, Post-Operative Care, Ambulatory Surgicenters. \\
\hline 7 & Drug Store Pharmacist & $\begin{array}{l}\text { Retail, Patient Records, Whole Sale, Patient History, Distribution, Drug Information, Compounding } \\
\text { and Dispensing, Clinical Services, Diagnostic Kits }\end{array}$ \\
\hline 8 & Community Pharmacist & $\begin{array}{l}\text { Patient Counseling, Therapeutic Monitoring, Drug Information, Compounding and Dispensing, Patient } \\
\text { Record and History. }\end{array}$ \\
\hline 9 & Hospital Pharmacist & $\begin{array}{l}\text { Drug Information Provider, Recommend Drug Therapies, Patient Care, Compounding and Dispensing, } \\
\text { Nutritional Consultant, Document/Report Examination. }\end{array}$ \\
\hline 10 & Critical Care Pharmacist & $\begin{array}{l}\text { Neuro-Trauma Pharmacist, Pediatric Pharmacist, Cardiology Pharmacist, Oncology Pharmacist, ICU } \\
\text { Pharmacist. }\end{array}$ \\
\hline 11 & Nuclear Pharmacist & $\begin{array}{l}\text { Hospitals, Imaging Centers, Radioactive Diagnostics, Radiopharmaceuticals, Radiation Safety, } \\
\text { Dispensing Officer. }\end{array}$ \\
\hline 12 & Analytical/Quality Control & $\begin{array}{l}\text { Quality Control, Quality Assurance, Method Development, IPQC, GMP, Documentation, Biostatistics, } \\
\text { Structure Elucidation, Validation, Diagnostic Labs, Bioassay. }\end{array}$ \\
\hline 13 & Academics & Teaching, Research, Higher Studies, Doctoral, Post Doctoral, Consultants. \\
\hline 14 & Materials Management & Stores, Warehouse, Production Planning and Inventory Control. \\
\hline 15 & Documentation & Patient Screening, IPR Organization, Documentation for GMP, ISO, FDA, NDA. \\
\hline 16 & Regulatory & Government Associations, FDA, Drug Inspectors, Drug Registration Filing, IPR, Forensic Department. \\
\hline 17 & Consulting & Method Development, Problem Solving, Data Processing, Project Handling. \\
\hline 18 & Drug Information Specialist & $\begin{array}{l}\text { Data Base Research, Data Development, Pack Inserts, Scientific Literature Reviewer, Public } \\
\text { Awareness. }\end{array}$ \\
\hline 19 & Government Jobs & Government Hospitals, FDA, Govt Analyst, Scientists in CSIR, ICMR, CDRI, DCI, Excise. \\
\hline 20 & Military Pharmacist & Army Pharmacist, Navy Pharmacist, Air Force Pharmacist. \\
\hline 21 & Opportunities Abroad & $\begin{array}{l}\text { Research, Academics, Drugstore Pharmacist, Pharmacy Manager, Higher Education, Consultant, } \\
\text { Industry: QC/QA, RandD, Production. }\end{array}$ \\
\hline 22 & Higher Education & $\begin{array}{l}\text { Master of Pharmacy (M. Pharma), Master of Science (M. S), Master in Business Administration (MBA), } \\
\text { Master in Technology (M. Tech.), LLB, Doctoral Research (Ph. D.), Bioinformatics/Biotechnology, } \\
\text { Courses in IPR/Regulatory Affairs. }\end{array}$ \\
\hline 23 & Entrepreneurship & Starting Pharma Unit, Retail/Wholesale/loan License/Testing Lab \\
\hline 24 & Others & $\begin{array}{l}\text { Medical Transcription, Technical Support Services, Project Management, Logistics, Journalism } \\
\text { (Technical Writing/Scientific Journalism), CADD, BPO, KPO, Advertising, Medical Coding. }\end{array}$ \\
\hline
\end{tabular}

\section{CONCLUSION}

Eventually, rehearsing drug specialists need to adjust the essential information and required aptitudes, therefore, they can build up their training and jobs to address evolving issues.

\section{ACKNOWLEDGEMENT}

Authors thank The Director, CT Institute of Pharmaceutical Sciences, Jalandhar and The Management, CT Group of Institutions, Jalandhar for their continuous support and motivation.

\section{FUNDING}

None

\section{AUTHORS CONTRIBUTIONS}

All the authors have contributed equally.

\section{CONFLICT OF INTERESTS}

The Author(s) declare(s) that there is no conflict of interest.

\section{REFERENCES}

1. Barnes E, Ashraf I, Din A. New roles for clinical pharmacists in general practice. Prescriber 2017;26-9. DOI: https://doi.org/ $10.1002 /$ psb.1558.

2. John C. The changing role of the pharmacist in the 21 st century. Pharm J 2018;300:7909.
3. Elfituri A, Almoudy A, Jbouda W, Abuflaiga W, Sherif FM. Libya's pharmaceutical situation: a professional opinion. Int J Acad Health Med Res 2018;2:5-9.

4. Nagavamsidhar M, Nikhila Y, Naveen KB, Qadrie ZL. A brief review on smoking and role of pharmacist in smoking cessation. Hosp Pharm 2018;13(Suppl A):279

5. Longo K. New patient care roles for pharmacists: value-based pay creates opportunities. Drug Topics 2018;162:14.

6. Qadrie ZL, Rehman S, Wafai ZA, Humaira A. Pharmacovigilance: process of detection, assessment, understanding and prevention of adverse effects: a review. World J Pharm Life Sci 2017;3:78-95.

7. Canadian Pharmacists Association Pharmacists. Scope of Practice in Canada; 2020. Available from: https://www.pharmacists.ca/pharmacy-in-canada/scope-ofpractice-canada [Last accessed on 10 May 2020].

8. Wani SUD, Gangadharappa HV, Ashish NP. Formulation, development and characterization of drug delivery systems based telmisartan encapsulated in silk fibroin nanosphere's. Int J Appl Pharm 2019;11:247-54.

9. Kakkar V, Wani SUD, Gautam SP, Qadrie ZL. Role of microspheres in novel drug delivery systems: preparation methods and applications. Int J Curr Pharm Res 2020;12:10-5.

10. Suman A, Qadrie ZL, Srikanth J. Assessment of the attitude, knowledge and practices of medical professionals about adverse drug reactions and their reporting during practice in government hospital and private setup. Int J Pharma Bio Sci 2018;9:189-93. 